\title{
Discussion on Financial Accounting Problems and Management Strategies of Enterprises from the Perspective of Standardization*
}

\author{
Meiling Xiao \\ School of Business \\ Kunming Metallurgy College \\ Kunming, China 650033
}

\begin{abstract}
Along with the continuous deepening of the socialist reform and rapid development of the economy, financial accounting work plays a very important role in the production and operating activities and the future development of enterprises. Therefore, it is necessary to standardize the financial accounting work of enterprises. However, at present, there are various problems in financial accounting work of most enterprises in China, which adversely affects the production and operation of enterprises. The paper makes a detailed analysis of the existing problems in enterprises' financial accounting work mainly from the aspects of system, personnel and institution setting, and puts forward corresponding improvement measures, hoping to help the standardization of financial accounting work and then promote the long-term and stable development of enterprises.
\end{abstract}

Keywords-standardization; financial accounting; management strategies

\section{INTRODUCTION}

As an important part of accounting work, financial accounting work exerts a positive role in promoting the production and operating activities and long-term and stable development of enterprises. With the continuous development of the social economy, enterprises have got better development opportunities, and also face more severe challenges at the same time. There also exist opportunities and challenges in enterprises' corresponding financial accounting work. Traditional financial accounting work cannot adapt to the development of modern enterprises, and the standardized financial accounting work is very beneficial to improving the competitiveness of enterprises. Currently, the research topic of all enterprises and government departments is how to better standardize the financial accounting work of enterprises. The current financial accounting work covers a wider range of links. From the beginning to the end of the business activities, it includes pre-accounting, accounting in the whole process and final accounting, all needing for standardization. Therefore, how to better standardize the financial accounting work is a

*Fund program: scientific research fund at school level of Kunming Metallurgy College in 2017: Research on the reform of teaching method of tax law from the perspective of enterprises' tax planning under the background of "replacing business tax with value-added tax". very important research topic. On the basis of the analysis of the contents, principles and significance of enterprises' financial accounting, this paper analyzes and studies the current existing problems in financial accounting within the enterprises, and elaborates on improvement measures in terms of the problems from some aspects such as the establishment and improvement of accounting system, rationalization of institution setting, enhancement of supervision and administration, improvement of personnel quality, and avoidance of illegal behavior, hoping to give accounting staff and enterprise leaders some suggestions to help enterprises better standardize financial accounting work, further promote the long-term and stable development of the enterprises, and finally accelerate the development of the national economy.

\section{RESEARCH BACKGROUND OF ENTERPRISES’ FINANCIAL ACCOUNTING}

In the initial period, the financial accounting of enterprises is to book, calculate, and send accounts for business operation, and all the links are done at the end of the whole business activities. However, with the rapid development of the social economy and increasing enterprise businesses, the simple financial accounting content can no longer meet the needs of enterprise production and operation. Therefore, based on simple financial accounting, we also need to make a budget for business activities to support operation and management of enterprises, and timely correct the deviations from the budget in the business activities. At present, the financial accounting within the enterprises mainly includes enterprise assets accounting, enterprise liabilities accounting, enterprise income accounting, enterprise cost accounting and enterprise profit accounting. The financial accounting work of enterprises is very important for their development. The degree of standardization is an important aspect of enterprise competitiveness, and the higher degree of planning is, and the greater market competitiveness is.

Financial accounting work is of great importance to enterprises, so it should follow the principles of accuracy, timeliness and clarity. First of all, accuracy means that financial accounting of enterprises should reflect the financial status, operation and economic data of the enterprise in a true and accurate manner. Second, in terms of the principle of 
timeliness, the businesses of enterprises must be recorded timely to ensure the consistency of the actual business and accounting accounts in time. Finally, for the principle of clarity, the accounting account of enterprises must be clear at a glance, and clearly reflect the operating results and financial status of enterprises, so that financial personnel and leaders can clearly understand the financial situation of enterprises and make a correct work instruction.

The financial accounting management work is of great significance for the development of enterprises. It can mainly reduce enterprises' business risks and optimize their resource allocation. Standardized enterprise financial accounting is very beneficial to improving the utilization of accounting information within the enterprise. The standardization of enterprises' financial accounting should be based on the actual situation of enterprises, so that the standardization of enterprises' financial accounting will be more operational and executable.

In short, enterprises' financial accounting work plays a very important role in promoting the business and further longterm development of enterprises. The current financial accounting work mainly includes pre-accounting, accounting in the whole process and post-accounting of business activities. That is to say, we should make a budget before the project work begins, conduct regular accounting work in business activities, check the implementation of the budget, make timely adjustments to the portion that exceeds the budget, and carry out financial accounting work of the whole project after the business activities complete. We should also follow the principle of accuracy, timeliness and clarity in enterprises' financial accounting work. As a further management of enterprises' financial accounting, standardized enterprises' financial accounting work plays an important role in promoting the development of financial accounting work of enterprises, and is also the main research content of the enterprises' financial accounting management at present.

\section{ANALYSIS ON THE PROBLEMS OF ENTERPRISES' FINANCIAL ACCOUNTING MANAGEMENT}

At present, there are still some problems in enterprises' financial accounting management, mainly including low quality of personnel, imperfect system, unreasonable allocation of institutions, imperfect supervision system and so on. These problems will be analyzed in detail below.

First of all, the financial accounting system of enterprises is not perfect. At present, imperfect financial accounting system exists in the most enterprises, especially small and mediumsized enterprises, and makes the financial department of the enterprise don't have clear understanding on the subject when conducting accounting, which causes the financial department to have many problems in accounting. Although some enterprises have formulated a financial management system, the financial personnel does not pay much attention to it, therefore, the accounting system has not been effectively implemented. The establishment of accounting books is not based on accounting system, and most books are established to cope with inspections. The setting of accounting subjects is not in accordance with the accounting system, which causes a lot of problems of accounts inconsistent with reality in financial accounting work. At the same time, there are still some human factors seriously affecting enterprises' financial accounting work in the accounting work.

Second, many enterprises do not have a reasonable allocation of accounting personnel and institutions at present. There are related requirements for allocation of enterprises accounting personnel and institutions in accounting regulations. While many enterprises do not follow the standard to allocate, and most enterprises have not set up special independent accounting institutions under the circumstances that they consider the operating cost. Many enterprises appoint people by favouritism in the selection and hiring of accounting personnel, and the recruited accounting managers are their relatives. These people have poor professional quality, which causes low accuracy, timeliness and clarity of financial accounting and then affect the development of enterprises.

Third, enterprises lack the supervision and management of financial accounting. The internal supervision mechanism of enterprises is not perfect due to the unreasonable measurement and acceptance, cost accounting and financial check. The interference of enterprise managers in financial accounting work makes it difficult to realize the supervision and management of enterprises, which causes that financial accounting lacks effective supervision and management and becomes formalistic, and it does not provide guidance for the management of enterprises and the decision-making of managers.

Fourth, the professional quality of financial accounting staff is poor. The financial accounting work of an enterprise has a very important position in the enterprise, and accounting is also a very professional and technical work. This has high requirements in professional knowledge of enterprise accounting personnel, and also needs the accounting personnel of enterprises to have certain accounting work experience. However, at present, although practitioners of enterprise financial accounting have obtained relevant accounting certificates, this is often because they are trained in obtaining certificates, and they have not thoroughly studied the professional knowledge of accounting work and have been less capable of operating the professional accounting software. At the same time, they do not understand the laws and regulations of the accounting industry and lack the professional ethics of the accounting profession. Moreover, most enterprises appoint people by favouritism in the appointment of financial accounting personnel, appoint their own relatives to serve as financial staff, which makes the professionalism of financial work greatly discounted. The serious influence of human factors has led to the distortion of financial accounting. These will have a negative impact on the financial work and the next development of enterprises.

Fifth, there are some irregularities during the financial accounting process. Currently, many middle and small-sized enterprises have some irregularities in financial accounting. For example, some small-sized enterprises do not issue invoices and only obtain the receipt when business occurs, to reduce the cost of obtaining the original documents. This has led to the distortion of the original certificate of the business 
activities of enterprises, and enterprise's operating activities cannot be truly reflected, therefore, the financial accounting principle is also destroyed.

Finally, enterprises do not conform to the provisions of the accounting system when establishing accounts. At present, many enterprises do not realize the important role of accounting management in the development of enterprises. They believe that there is no need to establish accounts within the enterprise, and the establishment of accounts is only for checking the inspection of the tax authorities, especially the books on value-added tax invoices. Even if many enterprises have accounts, they do not follow the relevant rules and regulations of accounting management, and the accounting subject they have established is not reasonable. There are still many discrepancies between the actual situation and recorded information of financial accounting, which makes the account book of enterprise lose its original meanings. This phenomenon makes the financial accounting work hard to carry out and brings various problems.

In short, many enterprises do not have a deep understanding of the importance of financial accounting work for the development of enterprises, which leads to a variety of problems in their financial accounting work, mainly including imperfect financial accounting system, unreasonable allocation of personnel and institutions, lack of effective supervision of financial accounting, and low professional quality of financial accounting staff. There will be some irregularities in the accounting work, and enterprises do not follow the regulations of accounting system when establishing accounts. These problems have led to the failure of financial accounting work to originally promote the development of enterprises.

\section{STANDARDIZED MANAGEMENT OF ENTERPRISES' FINANCIAL ACCOUNTING}

In view of the above problems in enterprises' financial accounting at present, the corresponding solutions will be proposed below, hoping to promote the standardized management of enterprises' financial accounting.

First, we must establish and improve the financial accounting system of enterprises. For the establishment of the enterprises' financial accounting system, government sectors and financial and taxation departments should actively communicate with all sectors of society, conduct in-depth investigation and research, widely listen to the opinions of all walks of life, actively improve the financial accounting system, and strengthen the legislative work, so that the financial accounting work of enterprises is more standardized. Meanwhile, the government and the financial and taxation departments should strengthen the efforts to regulate all violations of laws and regulations in the financial accounting work within the enterprise, severely deal with the phenomenon of untrue information and operation violations, and reduce fraudulent practices within the enterprise. Moreover, the enterprise should also actively promote the establishment and improvement of financial accounting system, standardize the working process of financial accounting, and make the financial accounting work of enterprises more standardized and regularized.
Second, we must reasonably allocate personnel and institutions in financial accounting work. In order to maintain the relative independence of accounting work in the business activities of enterprises, special accounting institutions and accounting staff should be set up within the enterprise. In the selection of accounting personnel, enterprises should openly recruit, select outstanding talents with strong professional ability, and avoid the phenomenon of using relatives and acquaintances. Enterprises should give accounting personnel a certain level of improvement in salary, and also should prohibit accounting personnel from doing a part-time job in multiple enterprises at the same time, to prevent internal information leakage and cause losses to the enterprise. In terms of organizations and posts setting of enterprise accounting work, enterprises must at least establish accounting audit post, general account management post, cashier post and detailed account post. The accounting audit post are mainly responsible for financial accounting, fund preparation, and accounting and property inventory, so that enterprise funds can be properly allocated. The general account management post mainly prevents the excessive interference of the enterprise leaders to the accounting work to ensure the relative independence of the financial work, and mainly takes charge of cost accounting, statement preparation and custody of financial treatment. The cashier post is mainly in charge of enterprises' daily monetary fund management, journal recording, and checks management. The detailed account position is mainly responsible for enterprises' tax declaration and registration management of the detailed account. Mutual supervision and management should be carried out among different posts to promote the standardization of enterprises' financial accounting.

Third, we must strengthen the supervision and management of financial accounting work. Enterprises should set up a special supervision and management system for financial accounting work, regularly supervise and inspect the financial accounting work, and seriously deal with problems, and give certain rewards to the accounting personnel who perform better to stimulate the enthusiasm of accounting personnel. Moreover, as the internal self-supervision of enterprises often exists some loopholes and favoritism, the supervision of enterprises' financial accounting is hard to be realized. At this time, the supervision and management of intermediaries is required, especially the taxation department and the audit department. They must strictly investigate the illegal behaviors in the accounting management of enterprises, purify the accounting department of enterprises, and promote the standardization of internal financial accounting work.

Fourth, we must improve the professional quality of enterprises' accounting practitioners. Enterprises should openly recruit accounting personnel and select accounting personnel with professional knowledge and work experience, so that they can serve the enterprise faster and better. Enterprises should increase the training of accounting practitioners. The business activities of enterprises are constantly changing, and the contents and methods of financial accounting will also be adjusted and changed accordingly. These require the accounting personnel in the enterprise to continuously learn and constantly grasp new knowledge to adapt to the ever-changing financial accounting work. The 
trainings carried out by enterprises are mainly reflected in the following aspects. The first is the training of vocational skills, including relevant laws and regulations, and institutional norms in financial accounting, and how to use the related software. The second is the training of professional ethics. Enterprises will provide professional ethics training for accounting personnel to ensure that enterprise accounting personnel can firmly refuse when facing bad practice and ensure the accuracy of enterprise accounting information.

Fifth, we must standardize the financial accounting work of enterprises to avoid irregularities. Irregularities in financial accounting work are very detrimental to the development of enterprises, so we should absolutely avoid them. In the process of financial accounting, a reasonable arrangement should be made for the position of accounting personnel, and there should be clear job responsibility statements for the duties and contents of each position, so as to really accomplish the implementation of the individual responsibility. There should be a strict approval authority system for the financial expenditure of enterprises to ensure that all expenditures have undergone strict examination and approval and to avoid the occurrence of unreasonable expenditure. In order to avoid irregularities, the accounting staff must be proficient in the new technology, new rules and related laws and regulations of the industry, so enterprises need provide regular training for accounting personnel.

In conclusion, aiming at the problems existing in the financial accounting work of enterprises, how to standardize the financial accounting work of enterprises can be realized from the following aspects: establish and improve financial accounting system, enhance the reasonable allocation for enterprise's accounting personnel and institution, reasonably arrange accounting posts of finance department, and set up at least four operating posts, namely, accounting audit post, general ledger management post, cashier post and detailed account post. At the same time, supervision and management of financial accounting work should be strengthened, including internal supervision and supervision of external financial institutions and audit institutions. It also advocates improving the professional quality of accounting personnel, carrying out regular training for their specialized knowledge and professional ethics to enable them to master the new knowledge and skills of accounting work. Finally, it proposes that the enterprise should avoid the illegal financial accounting behavior, which may bring financial loss and harmful effects for the enterprises. The standardization of accounting work of enterprises has obvious promotion effect on the production and operation activities of enterprises, and it is also very important for the long-term development of enterprises. Therefore, the leaders and financial staff of enterprises should attach great importance to the standardization of accounting and ensure the accounting of enterprises.

\section{CONCLUSION}

The financial accounting work is of great significance to the development of an enterprise. Its standardization is a longterm and arduous task which requires the joint efforts of enterprises, governments and tax authorities. Through the analysis and elaboration of the main content, the followed principles and the significance of the standardization of financial accounting, this paper conducts a deep analysis for the problems existing in the current accounting work mainly from the perspective of the system, personnel allocation, organization structuring and personnel quality. This paper further puts forward corresponding improvement measures, this paper further puts forward corresponding improvement measures from the following aspects: how to better establish and improve financial accounting system, enhance the reasonable allocation for enterprise's accounting personnel and institution, set up at least four operating posts, namely, accounting inspection post, general ledger management post, cashier post and detail account post when the posts of finance department are arranged. Mutual supervision should be carried out between posts, and part-time work between incompatible posts should not be allowed. At the same time, supervision and management of financial accounting work should be strengthened, including internal supervision and supervision of external financial institutions and audit institutions. It also advocates improving the professional quality of accounting personnel, carrying out regular training for their specialized knowledge and professional ethics to enable them to master the new knowledge and skills of accounting work. Finally, it proposes that the enterprise should avoid the illegal financial accounting behavior. Through the elaboration of these aspects of improvement measures, this paper aims to improve the standardization process of accounting work, ensure the smooth progress of production and operation activities of enterprises, and further promote the rapid and stable development of enterprises. In conclusion, enterprises should fully consider various influencing factors when standardizing accounting work, and combine with the actual situation of enterprises, based on a deep understanding of the problems existing in the internal accounting work of enterprises, establish and improve the internal accounting system. The relevant departments of government should also increase law enforcement and continuously promote the standardization of enterprise accounting.

\section{REFERENCES}

[1] Huang Xingtao. How to Strengthen the Planning Management of Enterprise Accounting [J]. Enterprise Reform and Management, 2015 (06): 119-120.

[2] Ren Jie. Discussion on Standardized Management Measures of Enterprise Accounting [J]. China Business (Theoretical Research), 2013 (20): 58-59.

[3] Zhang Yingdong. Discussion on Standardized Management Measures of Enterprise Accounting [J]. China Business \& Trade, 2013 (15): 40-42.

[4] Su Mingjun. Analysis on the Planning Management Measures of Enterprise Accounting [J]. Technology Innovation and Application, 2016 (08): 271.

[5] Zhang Wenbin. On How to Realize the Standardized Management of Enterprise Accounting $[\mathrm{J}]$. Chinese Enterprise Accounting of Villages and Towns, 2014 (01): 114-115. 